\title{
The Construction of the Mediterranean Refugee Problem from the Italian Digital Press (2013-2015): Emergencies in a Territory of Mobility
}

\author{
INÊS VIEIRA, Centro Interdisciplinar de Ciências Sociais - Faculdade de \\ Ciências Sociais e Humanas
}

\begin{abstract}
The Mediterranean Sea is a historical stage of mobilities and has been a witness to important movements of people and goods since ancient times. In this liquid territory, different social processes of globalization can be observed; yet, in recent years, it has been predominantly depicted as an emergency scene, a crossing platform for those in search of refuge in Europe. This scenario becomes connected to a set of dimensions of securitization and quests for control that redirect the debates about national and European responsibilities regarding maritime territories. In this article, this issue is addressed exploring the construction and development of the social problem of refugees in the Mediterranean, departing from a frame analysis of news items thematically filtered from the digital platforms of two Italian newspapers in 20132015. The problem is contextualized in time and content progression, deepening the framing of some critical events, and reframing the Mediterranean as a referent/emergent territory of mobility.
\end{abstract}

\section{KEYWORDS}

Mediterranean Sea, press analysis, frame analysis, refugees, territory of mobility

\section{Introduction}

The Mediterranean Sea is a historical stage of mobilities: it has witnessed important movements of people and goods since ancient and medieval times. Its profile has changed throughout history, along with important changes in the transnationalised notion of human mobility. This area witnesses different social processes of globalization, which in part can be described through metaphors of liquidity, nomadism and flow (Bauman 2000; Urry 2007; Urry \& Sheller 2006). It can be seen as a special non-land territory, a unit of space subject to a certain authority, which sets some frontiers on an anthropological sense of place (culture located in space and time) but mainly on a political sense of order (that enables its defence) (adapted from Baudin 2014). In recent years, the Mediterranean has been generally depicted as an emergency scene, a crossing platform for those in search of shelter, the southern entry - perceived as a political problem - to Europe. 
The emergency represented by human mobilities in the Mediterranean area in the recent past has been depicted as strongly connected with different dimensions of securitization and quests for control (Castles, de Haas \& Miller 2014; Mazzella 2014). Security issues range from the original context of people on the move, escaping situations of conflict or persecution, to the image of their European arrival as invaders provoking the need for further border control, to recent strongly pronounced fears of terrorist threats. The last years have also witnessed a shift in the territorial focus of attention, both regarding the places of humanitarian emergency (from Central to Eastern Mediterranean routes, from Italy to Greece) and entities responsible for providing an institutional reply to this emergency (from single member States to the European Union).

These dimensions are not considered here as objects of realistic verification, but rather as in need of framing in a constructionist perspective (Berger \& Luckmann 1966), considering the construction and development of the Mediterranean refugee situation from 2013 to 2015 . For this purpose, after providing a set of readings on this problem in current social sciences, news items filtered from the web platforms of two Italian newspapers (Corriere della Sera and La Repubblica), tagged on the topic of 'Mediterranean refugees', will be subjected to frame analysis. This analysis will, first, contextualize the temporal evolution of this problem (2000-2015); second, approach the progression of critical events/focus topics from 2013 to 2015; and third, deepen the analysis on $5 \%$ of the news items, with one frame per year. Departing from a critical interrogation of the social and political forces that frame dominant comprehensions of this emergent social problem, a reframing of the Mediterranean as a referent/emergent territory of mobility (of refugees) will be provided.

\section{Readings on the construction of the Mediterranean refugee problem}

The Mediterranean can be presented as a stage of mobilities. One of the main points emerging from the recent political debate on the Mediterranean refugee situation is the limitedness of closed territorial categories such as the nation/State when facing this phenomenon of multiple scales, with the refugee status recognition determined by United Nations (UN) regulations and applied through European Union (EU) jurisdiction. In a context of turbulent waves of mobilities, hierarchized and encompassing both globalism impulses and sedentary bias (Urry 2007), the Mediterranean becomes an interesting context to observe the construction of refugee movement as a globalized political problem. Here, the idea of an international policy regime is developing: with collective devices reuniting different social actors, sectors and spatial contexts, and originating a type of cosmopolitan governance through the creation of commissions, world forums and consultation processes, frontiers are controlled through regional cooperation and devices are produced to restrain population movement (Mazzella 2014).

The idea of belonging to a territory is seldom opposed to the idea of mobility, implicitly considering the territory as an anchor and a space of tradition, contrary to movements of populations. This view is influenced by a State vision, which tends to value the fixed person, while considering the mobile person as a problem (Baudin 2014). Another view on territory, more focused on its features, illustrates how the organization of social life (mainly) in the city is no longer as heavily centred on the 
productive life, but on opportunities for consumption for play and pleasure, in contrast to a third type - securitized, avoidable territories, where basic rights of citizenship must be fought for (Baptista 2004). A territory such as the Mediterranean, for a social group such as refugees, might be better understood in this third securitized category, reframed here as a liquid territory of mobility, under battled regulations of a transnational space.

In the context of this mobility and citizenship debate, refuge becomes a privileged locus of juridical construction (United Nations High Commissioner for Refugees UNHCR 2010). The popular usage of the term refugee tends to apply to all kinds of forced migrants, despite the majority of forced migration drivers not being recognized by international refugee law - and even when they are, a refugee is only considered as such after the full analysis of the asylum request ${ }^{1}$. The context of a growing demand for asylum is indeed accompanied by a crisis in its jurisdiction (Mazzella 2014). Limited rights for refugees when compared to other citizens can be identified as unequal due to the lack of respect for broader mobility rights, retained as fundamental human rights: the free decision to move or not to move; the right to move to another country; and the right to settle in another country (de Lucas 2016, 22).

Most of the people of concern in refugee-like situations remain within their country of origin or travel to neighbouring countries ${ }^{2}$. Journeys from the global South towards the global North, as seen in the European fearful imagery of migrant mass invasions, would actually require a set of capitals that most migrants, and particularly forced migrants, struggle to access. Considering the available financial, social and other types of capital, around $80 \%$ of refugees remain in poor countries of Africa, Asia, the Middle East and Latin America (Castles, de Haas \& Miller 2014, 223). In a global context of strong inequalities, capitals of mobility must indeed be equated in regards to their distribution, access and capacities of usage, thus allowing us to understand why mobility is a generalized possibility, but not an equally attainable one (Baptista 2012; Kaufmann, Bergman and Joye 2004).

Forced migrations are particularly marked by inequalities, and the Mediterranean in recent history is predominantly seen as a space of forced migrations. Such a space is populated by people from critical areas, vulnerable parts of the global South where States tend to be weak and mobility gets engendered by unstable economic, social and environmental structures. Once people are forced to migrate, they encounter legal and social systems that set up many restrictions and limitations to their mobility and settlement possibilities. Their journeys become long and complex, involving many (exploitative) relations, various transit points and unsafe modes of transport (Urry 2007).

\footnotetext{
${ }^{1}$ On this matter, when compared to English, Italian language provides a broader spectrum of concepts on the refugee topic, particularly with the distinction between profugo (forced migrant, mainly due to political reasons), richiedente asilo (a profugo that asked for asylum) and rifugiato (a profugo that asked for asylum and to whom it was conceded). Regardless of language, different international campaigns have been started in recent years in order to promote the de-illegalization of people on the move (referring to undocumented instead of illegal migrants) and to produce a clearer identification of the Mediterranean as a stage of refugee-seeking much more than (economic) migration.

${ }^{2}$ This can explain, for example, why the top-3 refugee-receiving countries in 2011 were Pakistan, Iran and Syria (Castles, de Haas and Miller 2014, 224) instead of wealthier countries. This also allows us to better understand the extensive impacts in population dynamics resulting from the Syrian conflict.
} 
Increased border controls and the shrinking of regular migration possibilities lead to the reliance of migrants on smuggling. When dependence on smugglers and other migration facilitators gets high, it can generate exploitative forms related to human trafficking. A distinction must be made, however: firstly, although both smuggling and trafficking involve the undocumented movement of people, and both smugglers and migrants profit, they are unequal partners in a commercial transaction; secondly, the deception, coercion and exploitation of the moved person must be considered (Castles, de Haas \& Miller 2014, 236). Human smuggling and trafficking can be considered a $21^{\text {st }}$ century problem if compared against the $20^{\text {th }}$ century juridical construction of the problem of refugees (particularly with the Convention of Geneva, 1951, in UNHCR 2010); formal definitions of human trafficking and smuggling are embodied in the UN Convention against Transnational Organized Crime (UNODC 2004), adopted by the UN General Assembly in 2000. These timely and distinct UN Conventions encompass two different considerations: first, the refugee problem was addressed as a juridical problem to be dealt with in a political recovery phase (after the world wars) and in the arrival contexts; second, the smuggling/trafficking problem was addressed as a criminal problem of global scale, which should be kept as far away from the EU as possible. The association of these two fields of differentiated political construction might be critical for the figure of the refugee, who becomes progressively more associated with criminal paths.

Since the 1990s, the refugee topic became a major political issue. Asylum became politicised through extreme-right mobilization, attacks against foreigners and asylum seekers, and the reaction of European states that took migrant-restrictive measures rather than tackling this rebirth of racism. Different measures suggested the forging of Fortress Europe: changes in national legislation to restrict access to refugee status; temporary instead of permanent protection regimes; non-arrival policies to prevent undocumented migrants from entering Europe; diversion policies, by declaring countries bordering the EU to be "safe third countries", where asylum seekers could be returned to had they crossed these transit countries; restrictive interpretations of the 1951 UN Refugee Convention, excluding for example the persecution by 'non-state actors' (like the Taliban in Afghanistan); and limitative European cooperation on asylum and immigration rules (Schengen Convention, Dublin Convention of 1990 replaced by Dublin Regulation in 2003, among other EU agreements). In sum, "The refugee regime of Western countries has been fundamentally transformed (...) from a system designed to welcome Cold War refugees from the East and to resettle them as permanent exiles in new homes, to an exclusionary regime, designed to keep out asylum seekers from the south" (Castles, de Haas \& Miller 2014, 227). With a resurgence of right wing and populist media discourses, associating asylum seekers with narratives of increasing crime rates, fundamentalist terrorism and overstretched welfare systems, the public appeal for restrictive measures grew more forceful.

\section{Methodological approach}

This article aims to explore the recent (2013-2015) discursive construction of the social problem of Mediterranean refugees. In order to interpret the discourses underlying this construction, we present a frame analysis of news from two digital platforms of the Italian newspapers with the largest circulation: Corriere della Sera (CS) and La Repubblica (LR). In editorial terms, considering other politicized issues 
in these newspapers, both have been identified as moderate in the Italian press, with a more neutral/"propaedeutic" positioning in CS, balancing central/left/right orientations, and a more active political suggestion in LR towards a central/left progressive positioning (Papuzzi 2010, 96).

A driving hypothesis of this article is that the visualization of Mediterranean refugees (through widely disseminated photos and videos reporting shocking scenes of refugees journeys, but also visual and verbal narratives associating this problem to publicly legitimizing political entities such as the EU and the UN) had an important effect in the social construction of this problem. The problem of refugees arriving through the Mediterranean sea already existed prior to 2013-2015: it was reflected in social sciences literature, testified through refugee biographic interviews, it generated debates and demonstrations by social movements (related to the promotion of social/cultural diversity and to post-colonial complaints about issues such as racism and human illegalization), and it appealed to a part of media consumers (for example, readers of newspapers such as LR). Nonetheless, this issue was not perceived as a problem for the majority of public opinion, nor was it clearly assumed as a priority for the international political agenda. The situation changed in the last years - for Europe in 2015, for Italy some years before but more pronouncedly after 2013.

Bringing a social constructionist perspective (Berger \& Luckmann 1966) to the issue is not meant to deny the existence of a realistic and critical phenomenon of large flows of vulnerable people trying to enter Europe through the Mediterranean Sea, but to enable critical interrogation of the social and political forces that shape dominant understandings of it. Media is here retained as a good platform from which to observe the social construction of this social and political problem, as it has "the power (...) to define the framework within which collective social reality is perceived, and consequently to shape the basis of social action" (Adoni \& Mane 1984, 331).

Within media studies, frame analysis is a useful methodological approach for understanding evolutional angles of observation and fields of meaning constructed around certain events and topics. These require a shared repertoire of patterns of cognition, perception and interpretation, linking producers and receptors of news (Entman 1993). Frames can be understood as thematic units inside news, different (ontologically) from the topic of the narrative - more like an angle of observation or a type of experience of what is referred to in the news. They are powerful discourse keys, able to have an impact on knowledge production, individual socialization through interpersonal discussion, building public opinion and utilitarian uses of media by certain groups. Frames give shape to public dialogues about political questions, highlighting the role of media as information transmitters that enable citizens to interpret political dynamics and take consequent decisions (D'Angelo 2002). Retained as interpretative principles, frames are manifested in discourse through symbolic devices such as metaphors, examples, visual images and slogans, important in the organization of information in relation to broader cultural ideas. Formal aspects of news - such as location, size, frequency and information disposition - have an effect on the visibility of information. These aspects reflect the influence of certain critical events that are represented as contextually dramatic and motivate public attention as they break from daily routine. These critical events invite a collective definition or redefinition of a social problem when different stakeholders compete to assign a meaning to the evoked topic (Koziner 2015). 
Two levels of frame analysis are presented in this paper: a general level, through which we assess the frequency of news and critical events/focus topics per year, identified from the content of all filtered news ${ }^{3}$; and a detailed level, in which analysis is deepened for $5 \%$ of the news, chosen randomly within the same frame per year. For the latter, formal aspects of news, symbolic devices, problems definition, attributed causes and moral judgments are at the core of the analysis.

The main corpus of filtered news is composed of the results of the search for the terms 'Mediterranean refugees' in both newspapers' websites per year, contextualized in a more general search for 'refugees', 'displaced people' and 'migrants'. Considering the validity of spotted news for 2013, 2014 and 2015, total results as provided directly by the newspapers' web servers have a validity of $85 \%{ }^{4}$.

\section{Temporal evolution of the problem}

In order to assess the evolution of the number of news items per concept related to the theme of concern of this paper, the search on 'Mediterranean refugees' (rifugiati Mediterraneo - Chart 1) has been integrated into a more general search for news about 'refugees' (rifugiati), 'migrants' (migranti) and 'displaced people' (profughi). An overview of the results leads to three points that initially frame the construction of this social problem.

First, the number of news per newspaper is considerably different. In a general search for news between 2000 and 2010, it was seen that only La Repubblica consistently considered migrant and refugee-related issues. In this newspaper, for the first decade of the $21^{\text {st }}$ century, refugees and displaced people were already mentioned in a substantial (yet variable) number of news, while news about migrants evolved slowly; however, the case of refugees in the Mediterranean was practically non-existent.

Second, the problem emerges as a question of greater interest from 2011 onwards. In this year, the first peak appears for all categories and for both newspapers. This peak corresponds to a higher number of migrant arrivals and news about the relations between Italy and Libya, from the refoulement measures made possible through special negotiations between Berlusconi and Gaddafi, to growing discussions about the need to share the burden represented by migrants and asylum seekers within the Schengen area, to the upheaval of the Arab spring in Libya. After the death of Gaddafi (October 2011) and the reduction in migrant flows, the number of news about refugees and migrants, mainly in the Mediterranean, diminished consistently.

\footnotetext{
3 "News" is defined here as all valid digital newspapers' results, including editorials, special articles and chronicles. Each individual item is considered as "news". For the detailed analysis, one frame per year is examined in both newspapers; news are randomly chosen from different sections of the newspapers (note: within one frame, sections are seldom repeated), and long written news about the situation of refugees in the Mediterranean are preferred (rather than synthetic reports, in which the topic is worked only in a fragment of the narrative, or audio-visually focused news).

${ }^{4}$ Valid: 74/91 for 2013 (81,3\%), 117/129 for 2014 (90,7\%), 283/338 for 2015 (83,7\%). Invalid news includes double entries, other themes/wrong labels, and invalid links.
} 
Chart 1: Number of news about "Mediterranean refugees" on the websites of two Italian newspapers, 20002015

\section{"Rifuglati Mediterraneo"}

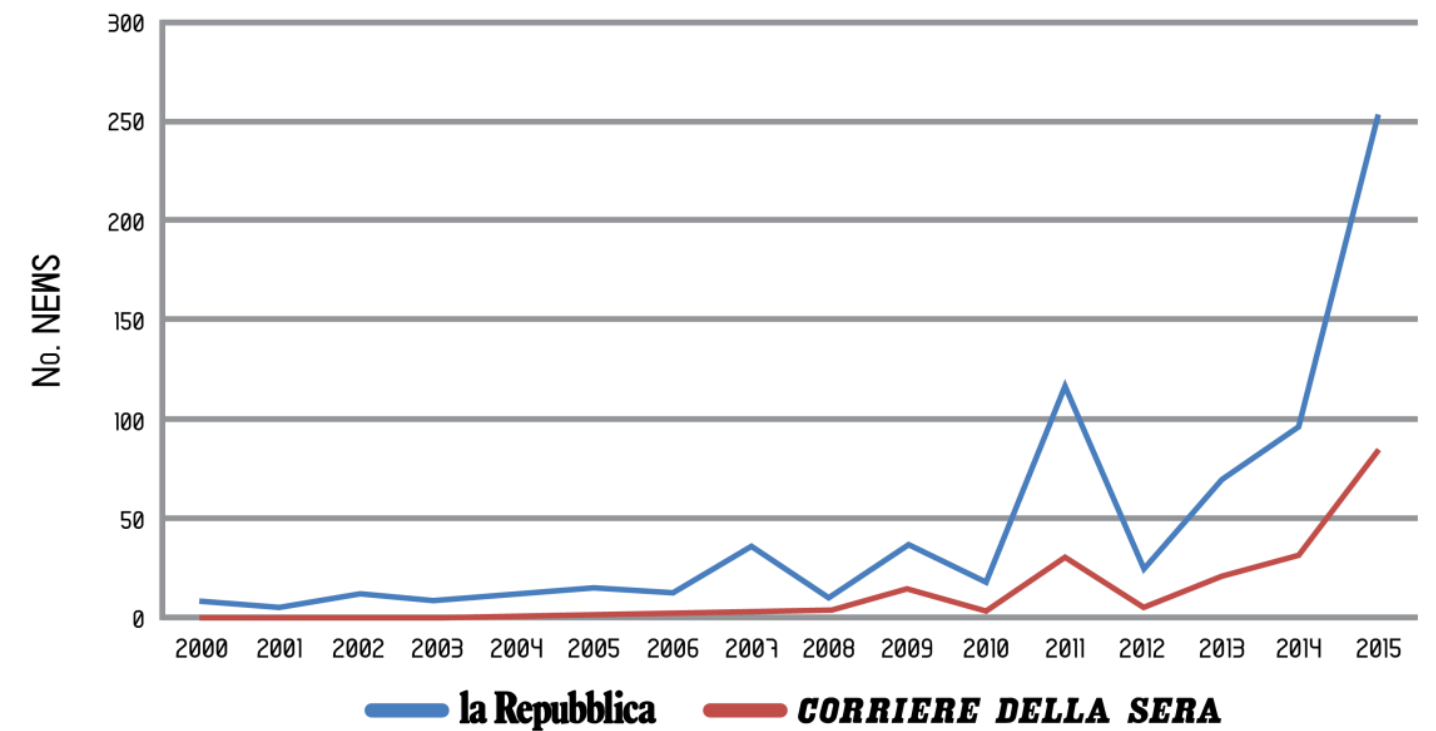

Source: La Repubblica and Corriere della Sera websites

Third, the issue had a steady, growing development in both newspapers from 2012 to 2014, with a remarkable unprecedented peak in 2015. Media attention rose particularly after the deadliest April 2015 shipwreck, reinforced by constant flows of arrivals up to the remarkable number of 1 million arrivals to Europe through the Mediterranean space in a single year.

If we frame the 2010-2015 time period with statistics about the progression of arrivals and deaths in the Mediterranean Sea (Chart 2), we can see that the number of deaths has grown steadily, yet is not proportional to the number of arrivals. To historically frame a peak of arrivals similar to the one for 2015, surpassing 1 million incomers, we would be required to go back to the time of the Second World War and Cold War. As a consequence of that former peak, important juridical constructions for the consideration of refugees were created. Of particular note is the Convention of Geneva of 1951, which defined the status of refugees within a set of conditions to recognize a legitimate asylum request (war or persecution due to race, religion, nationality, social group or political opinions), grounded in Article 14 of the Universal Declaration of Human Rights of 1948 (UNHCR 2010). The Convention of Geneva was considered the first substantial effort to address the problem of refugees in Europe in the aftermath of the wars, so a similar peak in movement, with a particular visualization effect, requires us to observe how this social problem will be politically dealt with upon its reconstruction in the beginning of the $21^{\text {st }}$ century.

The historical progression of sea arrivals and dead/missing persons (Chart 2) has prompted the identification of the Mediterranean Sea as the most dangerous frontier in the world (de Lucas 2016; IOM 2016). The steady-growing arrival number can be primarily related to strong demographic and economic inequalities, with an inverted 
proportion between Gross Domestic Product (GDP) and Human Development Index (HDI) levels for one region, and demographic growth rates for the other (de Lucas 2016). In recent years, though, this number has been increasing out of proportion, a fact that can also be related to aggravated push factors in origin countries (such as the degrading situation in Syria) and the strengthening of mobility possibilities (despite their dangerous features) between origin countries and the EU. The International Organization for Migration further adds, "Europe is the world's most dangerous destination for 'irregular' migrants, with the Mediterranean costing the lives of 3770 in 2015 " out of the world total estimate of 5400 deaths for the same year (OIM 2016)

Chart 2: Progression of arrivals and dead/missing persons in the Mediterranean Sea (2010-2015)

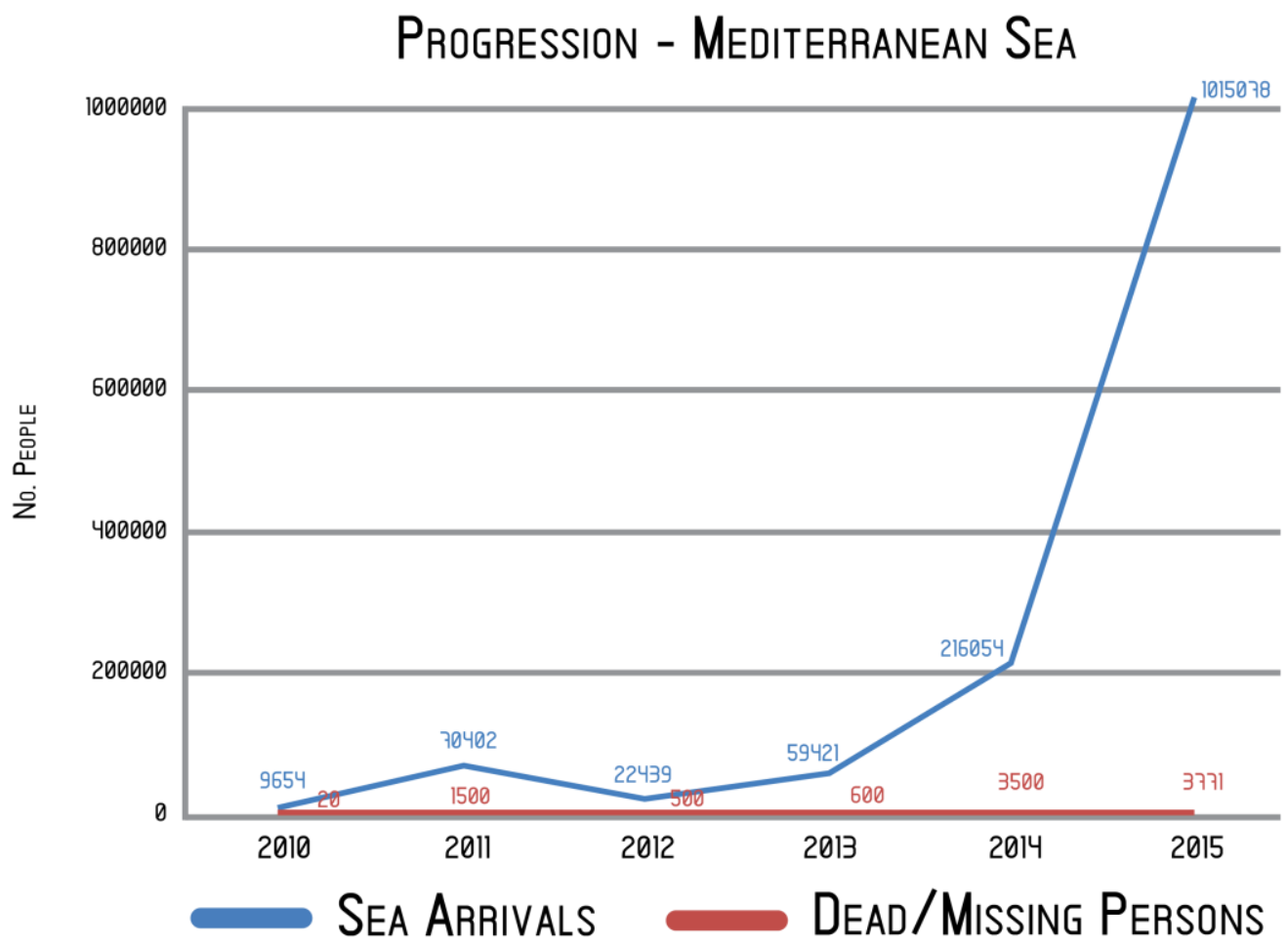

Source: UNHCR, 2016

Another empirical framing regards different routes taken by migrants and asylum seekers in the Mediterranean Sea. If we observe data on deaths by Mediterranean route in 2015 (Chart 3) we can perceive that, from September onwards, that which had in fact been a predominantly Central Mediterranean problem, involving mainly arrivals in Italian sea space, got redefined as also an Eastern Mediterranean problem

\footnotetext{
${ }^{5}$ These numbers, as well as those reported by UNHCR and presented in Chart 2, should be taken as estimates and minimums of the actual numbers (particularly regarding dead/missing persons), as they follow numbers reported by government entities, media, the UN or NGOs. More accurate data can be found in UNHCR population statistics on refugees, asylum-seekers, internally displaced persons (IDPs), returned refugees and IDPs, stateless and other people of concern, associating the arrivals with situations of juridical recognition and contexts of settlement (http://popstats.unhcr.org); or to militarycontrolled border apprehensions as reported by Frontex, particularly in the Annual Risk Analysis reports (http://frontex.europa.eu/publications). Search and rescue data, as provided by social relief organizations and summarized by UNHCR and IOM synthesis charts, is possibly the least consistent data, being nonetheless the most quoted statistics during and immediately after each critical event, particularly in the analyzed press sample.
} 
due to the larger number of deaths on that route compared with the Central route; Italy was now surpassed as the focus of attention.

Chart 3: Evolution of deaths in the three routes of the Mediterranean Sea (2015)

\section{Deaths by ROUte 2015}

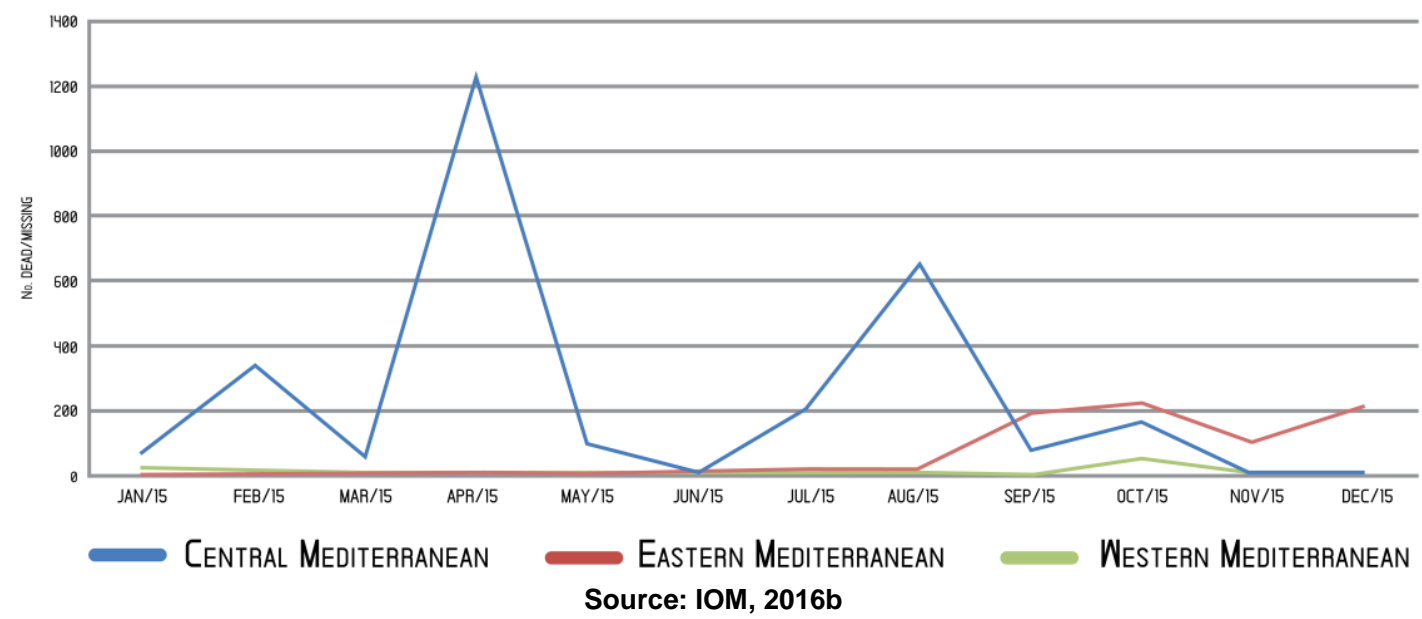

According to UNHCR (2015), by the end of 2014, 142628 people were considered of concern (refugees and refugee-like situations, asylum-seekers, IDPs, stateless) in Italy. The border control agency Frontex (2016a) states that this:

...Central Mediterranean route remained under intense migratory pressure in 2015, although the total number of migrants arriving in Italy fell (...). The main reasons for the drop were the shift of Syrians to the Eastern Mediterranean route and a shortage of boats faced by smugglers in the latter part of the year. Smuggling networks remain well established in Libya, where migrants gather before crossing the sea. Eritreans, Nigerians and Somalis accounted for the biggest share of the migrants making the dangerous journey.

As for the Eastern route, according to UNHCR (2015) mid-year statistics, 37602 people were considered of concern in Greece. The pressure on this route grew in the second part of the year, with Frontex (2016b) adding that:

In 2015, some 885000 migrants arrived in the EU via the Eastern Mediterranean route - over five times the number in 2014, which was itself a record year. The vast majority of them arrived on several Greek islands, especially Lesbos. (...) Most of the migrants on this route in 2015 originated from Syria, followed by Afghanistan and Somalia. There are also increasing numbers of migrants coming from sub-Saharan Africa. Most of the migrants continued their journeys north, leaving Greece through its border with the former Yugoslav Republic of Macedonia.

This shift to the East, highlighted by Frontex (the main collective framework for European border control) is of particular interest: it validates the anti-smugglers 
approach and maintains its need, adding to a global visualized evolution of the problem, from the "clandestinos" in the borders of (Mexico/USA and) Spain to Lampedusa/Italy and Greece.

\section{Thematic evolution of the problem}

Table 1: Synthesis of main frames on news about "Mediterranean refugees" in La Repubblica and Corriere dela Sera online (2013-2015)

\begin{tabular}{|c|c|c|c|c|c|c|c|c|c|}
\hline & \multirow{2}{*}{ FRAME } & \multicolumn{2}{|c|}{2013} & \multicolumn{2}{|c|}{2014} & \multicolumn{2}{|c|}{2015} & \multicolumn{2}{|c|}{ TOTAL } \\
\hline & & $\mathrm{N}$ & $\%$ & $\mathrm{~N}$ & $\%$ & $\mathrm{~N}$ & $\%$ & $\mathrm{~N}$ & $\%$ \\
\hline A & SHIPWRECHS/DISASTERS & 30 & $40.5 \%$ & 15 & $12,8 \%$ & 33 & $11,7 \%$ & 78 & $16,5 \%$ \\
\hline B & TERRORISM, WAR \& REFUGEES & 13 & $17,6 \%$ & 13 & $11,1 \%$ & 19 & $6,7 \%$ & 45 & $9.5 \%$ \\
\hline C & $\begin{array}{l}\text { CIVIL SOCIETY, CULTURAL } \\
\text { \& CHURCH SUPPORT } \\
\text { FOR REFUGEES }\end{array}$ & 11 & $14.9 \%$ & 5 & $4,3 \%$ & 38 & $13.4 \%$ & 54 & $11,4 \%$ \\
\hline D & $\begin{array}{l}\text { DETENTION CENTRES } \\
\text { \& REFUGEE CAMPS } \\
\text { (INC. AfRICA) }\end{array}$ & 4 & $5.4 \%$ & 5 & $4,3 \%$ & 3 & $1,1 \%$ & 12 & $2,5 \%$ \\
\hline$E$ & Refugees 〈he〉Settlement & 2 & $2.7 \%$ & 28 & $23.9 \%$ & 28 & $9.9 \%$ & 58 & $12,2 \%$ \\
\hline $\mathrm{F}$ & $\begin{array}{c}\text { ITALIAN/EU RESPONSIBILITY } \\
\text { AND OPERATIONS }\end{array}$ & 4 & $5.4 \%$ & 19 & $16.2 \%$ & 30 & $10,6 \%$ & 53 & $11,2 \%$ \\
\hline G & $\begin{array}{c}\text { ASYLUM LAW \& } \\
\text { EU PLAN 〈RELOCATION, } \\
\text { SMUGGLERS, BOATS〉 }\end{array}$ & 0 & $0,0 \%$ & 7 & $6.0 \%$ & 51 & $18,0 \%$ & 58 & $12,2 \%$ \\
\hline $\mathrm{H}$ & BORDER CONTROL \& WALLS & 1 & $1,4 \%$ & 2 & $1,7 \%$ & 18 & $6.4 \%$ & 21 & $4,4 \%$ \\
\hline 1 & StATS \& STUDIES & 0 & $0,0 \%$ & 5 & $4.3 \%$ & 14 & $4,9 \%$ & 19 & $4,0 \%$ \\
\hline$J$ & $\begin{array}{l}\text { GLOBAL POLITICS 〈UN, } \\
\text { OTAN, AFROMED, } \\
\text { GLOBAL PRIORITIES〉 }\end{array}$ & 5 & $6.8 \%$ & 4 & $3.4 \%$ & 26 & $9.2 \%$ & 35 & $7.4 \%$ \\
\hline H & $\begin{array}{l}\text { ITALIAN POLITICS 〈LAWS, } \\
\text { PARTIES, PRIORITIES〉 }\end{array}$ & 0 & $0.0 \%$ & 3 & $2,6 \%$ & 10 & $3.5 \%$ & 13 & $2.7 \%$ \\
\hline L & $\begin{array}{l}\text { REFUGEe LIVES \& } \\
\text { COMMEMORATIVE DAYS }\end{array}$ & 4 & $5.4 \%$ & 11 & $9.4 \%$ & 13 & $4.6 \%$ & 28 & $5.9 \%$ \\
\hline & TOTAL & 74 & $100,0 \%$ & בוו & $100,0 \%$ & 283 & $100.0 \%$ & 474 & $100.0 \%$ \\
\hline
\end{tabular}

Corriere della Sera (CS) and La Repubblica (LR) consistently published different numbers of articles (CS published around 30\% the number of news in LR). Despite some editorial variations, views on the issues, arguments, conflict positions and social actors quoted and in context did not differ widely.

Concerning the thematic evolution of the problem through the news, an overview of the critical events/focus topics of the total valid news (one main event/topic per news; Table $1^{6}$ ) is here presented. Concurrently, the detailed analysis of $5 \%$ of the news is made for one frame per year, retained as a representative angle for observing/creating the social problem presenting the disaster (2013 - Table 2, A), the Italian struggle of

\footnotetext{
${ }^{6}$ On the left column of each table, a corresponding letter informs which critical events/focus topics per year have been merged into each frame.
} 
settlement for thousands of incomers (2014 - Table 3, E) and EU debates towards a relocation plan (2015 - Table 4, G).

Table 2: Critical events/focus topics in Corriere della Sera and La Repubblica online (2013)

\begin{tabular}{|c|c|c|c|}
\hline & CRITICAL Events/Focus topics 2013 & No. NEWS & MONTH〈S〉 \\
\hline A & 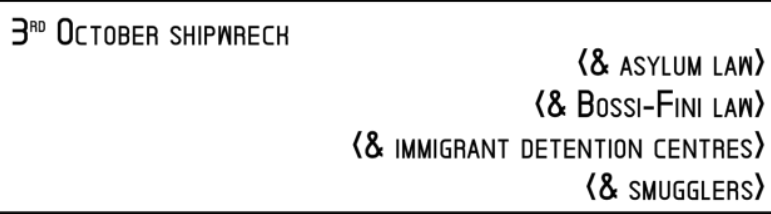 & $\begin{array}{l}29 \\
\langle 15\rangle \\
\langle 13\rangle \\
\langle 2\rangle \\
\langle 2\rangle\end{array}$ & 10,11 \\
\hline B & SYRIAN WAR & $\begin{array}{c}99 \\
\langle 6\rangle\end{array}$ & $06,08,09,11$ \\
\hline C & PoPe \& LAMPEDUSA & 6 & 07,12 \\
\hline C & CULTURAL SUPPORT FOR REFUGEES & 5 & $06,07,11,12$ \\
\hline $\mathrm{J}$ & BoLdRINI UNHCR - ItALIAN Chamber & 3 & 03 \\
\hline $\mathrm{L}$ & REFUgEe BIO/PATHWAYS & 3 & $06,08,10$ \\
\hline$D$ & LAMPEDUSA IMMIGRANT DETENTION CENTRE & 3 & 12 \\
\hline $\mathrm{F}$ & Political audit/elections & 2 & 01 \\
\hline$J$ & Arab SPRing \& MIGRATIONS & 2 & 04,05 \\
\hline $\mathrm{E}$ & Refugee relocation/Dublin & 2 & 05,07 \\
\hline $\mathrm{F}$ & MediterRaneAn RESPonsiblLITY IT - EU & 2 & 08 \\
\hline $\mathrm{B}$ & Terrobist threat AfroMed countries & 1 & 01 \\
\hline $\mathrm{D}$ & ReFugee camp Sudan & 1 & 01 \\
\hline $\mathrm{L}$ & World Refugee Day & 1 & 06 \\
\hline $\mathrm{B}$ & LiBYAN REFUGEES 2011 & 1 & 06 \\
\hline $\mathrm{H}$ & ALLOWED/FORBIDDEN SEA LANDINGS & 1 & 08 \\
\hline A & EGYPT SHIPWRECH & 1 & 10 \\
\hline$B$ & REFUGEES ORIGIN COUNTRIES & 1 & 11 \\
\hline$B$ & MALI WAR & 1 & 12 \\
\hline
\end{tabular}

Source: La Repubblica and Corriere della Sera websites, author's coding

Regarding social actors quoted as sources of relevant information, there is a dominance of Italian politicians, followed by international politicians (mainly from the EU, European Commission (EC) and UN), the third sector and the Catholic Church. The number of news reporting studies published by prominent councils and NGOs in the field (Italian Council for Refugees, Amnesty International) and in international control, and by monitoring and consulting organizations (Frontex, UNHCR, IOM) grew during this period.

In 2013 (Table 2), a general context of Afro-Mediterranean violence was established, particularly highlighting wars and terrorist threats in Libya and Syria and the pressing weight of human smuggling and trafficking, both from these countries and from other locations (particularly the Horn of Africa). In this year, within this sample of news, the Mediterranean is broadly presented as an Italian problem: it involves mainly boats coming from Libya and shipwrecks in the Italian or Libyan maritime spaces such that search and rescue operations, as well as highlights directed to the international community, are led by Italian social actors, from Lampedusa's residents to the formal political arena. The first big crisis, which led to the majority of news, was the $3^{\text {rd }}$ 
October shipwreck, with (previously unseen) more than 500 mortal victims. Following the October crisis, a set of debates (that pre-existed but had not previously had such momentum) was set in motion and consolidated up until 2015.

Table 3: Critical events/focus topics in Corriere della Sera and La Repubblica online (2014)

\begin{tabular}{|c|c|c|c|}
\hline & CRITICAL EVENTS/Focus tOPICS 2014 & No. NEWS & MONTH〈S〉 \\
\hline$E$ & $\begin{array}{r}\text { THOUSANDS OF INCOMERS } \\
\text { (\& REFUGEES OCCUPYING EMPTY BUILDINGS〉 }\end{array}$ & $\begin{array}{l}21 \\
\langle 6\rangle \\
\langle 5\rangle\end{array}$ & $\begin{array}{c}01,03,06,07,08 . \\
09,11\end{array}$ \\
\hline A & SHIPWRECHS 〈DIFFERENT DATES〉 & 15 & $05,06,07,08,09,10$ \\
\hline B & WAR/TERROR/CHAOS & $\begin{array}{c}8 \\
\langle 5\rangle \\
\langle 2\rangle \\
\langle 1\rangle\end{array}$ & $06,08,09,10$ \\
\hline$F$ & Mare Nostrum & $\begin{array}{c}8 \\
\langle 6\rangle\end{array}$ & $07,08,09,10,11$ \\
\hline $\mathrm{F}$ & RESPONSIBILITY ItaLY Vs EUROPE & 6 & $05,06,07$ \\
\hline $\mathrm{G}$ & ASYLUM LAW & 6 & $05,06,08,09$ \\
\hline $\mathrm{E}$ & Voluntary RELOCATION & 6 & $03,06,08,09$ \\
\hline $\mathrm{F}$ & ItALIAN OVERLOAD \& EU LACH OF COMMITMENT & 5 & 04,06 \\
\hline C & CULTURAL SUPPORT OF REFUGEES & 5 & $03,06,07,09$ \\
\hline $\mathrm{L}$ & REFUGEE BI0/PATHWAY & 5 & $01,05,08,09,12$ \\
\hline $\mathrm{L}$ & REFUGeE CHILDREN & 4 & $05,06,10$ \\
\hline 1 & PuBLICATION OF STUDY/REPORT & 3 & 06,08 \\
\hline $\mathrm{H}$ & RIGHT WING/LEFT WING ItALY & 3 & 06,12 \\
\hline D & PaIson Vs migration 〈Cyprus, Egypt) & 2 & 04 \\
\hline $\mathrm{D}$ & Detention Centres 〈private, Mafia) & 2 & 05,12 \\
\hline $\mathrm{J}$ & UNHCR VISITS/TESTIMONIES & 2 & 06,09 \\
\hline $\mathrm{B}$ & REFUGEES COUNTRY OF ORIGIN - CAUSES & 2 & 10,11 \\
\hline 1 & DEATH RECORD 201Ч: ЗЧІ९ PEOPLE & 2 & 12 \\
\hline $\mathrm{B}$ & Terrobist threat AfroMed & 1 & 01 \\
\hline $\mathrm{L}$ & World Day of Migrants and Refugees & 1 & 03 \\
\hline $\mathrm{J}$ & CLIMATE-INDUCED MIGRATIONS & 1 & 03 \\
\hline $\mathrm{H}$ & TURHISH WALL & 1 & 05 \\
\hline $\mathrm{E}$ & LEBANON REFUGEE'S OVERLOAD & 1 & 05 \\
\hline $\mathrm{J}$ & ITALIAN NAVY TRAINED LIBYAN SOLDIERS & 1 & 06 \\
\hline $\mathrm{H}$ & BORDER CONTROL & 1 & 07 \\
\hline $\mathrm{D}$ & COST OF REFUGEes 〈hOST, HEALTH) & 1 & 07 \\
\hline$B$ & ITALIAN ACTIVISTS HIDNAPPED IN SYRIA & 1 & 08 \\
\hline$G$ & FINGERPRINT RETURNS & 1 & 09 \\
\hline $\mathrm{B}$ & ITALIAN NUNS HILLED IN BURUNDI & 1 & 09 \\
\hline $\mathrm{L}$ & NETWORH TO ORGANIZE JOURNEYS & 1 & 11 \\
\hline
\end{tabular}

Source: La Repubblica and Corriere della Sera websites, author's coding

This first large shipwreck generated an Italian-driven accusation regarding European asylum policies (Dublin regulation) and operations (lack of search and rescue). Arguments departed from the paradox between a European identity based on universal values of human dignity, freedom, equity and solidarity, and its lack of commitment regarding the Mediterranean burden. Regarding the autonomy of European states for the management of asylum and migrations, Italy was condemned 
for former refoulement measures against Libya and for legislation that criminalized undocumented migrants, their facilitators and rescuers. Presented mainly in the solidarity and chronicle sections of the newspapers websites, images accompanying the news had mainly a deathful tone (emergency scene, covered corpses, boats full of people asking for help), and were also associated with European politics (portraits of politicians, visits to Lampedusa, symbolic cartoons). Regarding expressive metaphors and rhetorical figures, this event was presented as a terrible humanitarian tragedy, using a vocabulary of disaster, trauma, shame and crisis. Beyond presenting the Italian lack of control over this situation, Europe was presented as an insensitive military fort, defending a wall instead of the human beings that try to cross it - those presented as illegal people excluded from civil rights, except upon their visualized death - these victims had funerals of state. Considering the proximity of European elections and the visualization of this critical event, the shipwreck can be seen in this sample of Italian media as the turning point for the debate.

News published in 2014 (Table 3) reveal the consolidation of the problem, but rather than converging on a particular critical event, differently located and impacting shipwrecks were noticed, following an even larger number of news about the arrival of a rising number of refugees. News were recurrently related to other topics of emergent attention, particularly regarding asylum law and settlement possibilities.

A broader context of war, terrorism and chaos in countries of origin and in transit, particularly in the Afro-Mediterranean/Middle East area, was maintained through 2014. Debates in Italy were reinforced and divergences between the left and right wings became more notorious ${ }^{7}$, with extreme right politicians blaming Italian migrant protection measures and suggesting links with incoming terrorists. From Italy to Europe, discussions about the limitations of Mare Nostrum search \& rescue operation increased, up until its closure at the end of the year, forcing its replacement by Triton, a previously more geographically limited European military control operation. Arguments about Italy being the entrance and not the destination were reinforced by Italy's refusal to fingerprint refugees (which would tie them to Italy) as required by the Dublin Regulation; the respect for this regulation was reset only after Triton.

The discourse was particularly framed by the increase in refugee arrivals and the settlement chaos generated in Italy. In a sort of Malthusian rhetoric, the limited capacity of Lampedusa found an echo in the temporary solutions in cities such as Rome. Empty buildings and schools were presented as houses for hundreds of refugees waiting for the resolution of their situation and developments at the European scale. A second round of the emergency scene was depicted: inhuman conditions, lack of assistance structures, infinite bureaucratic waiting times and the pressure to continue a journey that was not foreseen to stop in Italy. The need for a controlled EU resettlement/relocation plan was strongly endorsed. Metaphorically, the predominant image was a "wave of refugees" who, after surviving all the nightmares associated with the journey to Lampedusa (smugglers, desert, Libyan detention centres, sea), end up in European ghettos or barrack-cities.

\footnotetext{
${ }^{7}$ The Italian general elections of 2013 had confirmed people's preference for the Democratic Party led coalition after a long period of Berlusconi right-wing government; regional elections, however, kept Veneto's and added extreme right representatives in Lombardy (2013) and Piedmont (2014).
} 
Table 4: Critical events/focus topics in Corriere della Sera and La Repubblica online (2015)

\begin{tabular}{|c|c|c|c|}
\hline & CRITICAL EVENTS/FOCUS TOPICS 2015 & No. NEWS & MONTH〈S〉 \\
\hline$A$ & SHIPWRECHS/BOAT ACCIDENTS & 32 & $\begin{array}{c}02,04,05,06,07, \\
08,09,10,11,12\end{array}$ \\
\hline $\mathrm{G}$ & RELOCATION PLAN EU & 24 & $05,09,10,11$ \\
\hline C & CULtURAL SUPPORT tO REFUGEES & 20 & $\begin{array}{l}03,04,05,06,07 \\
08,09,10,11,12\end{array}$ \\
\hline G & ANTI-SMUGGLERS PLAN EU & 14 & $04,05,06,07,08,09$ \\
\hline I & Stats/Studies & 14 & $\begin{array}{l}03,04,05,06,07 \\
08,11,12\end{array}$ \\
\hline$E$ & AGE OF MASS MIGRATIONS/THOUSANDS OF INCOMERS & 13 & $01,03,04,06,08,09$ \\
\hline $\mathrm{B}$ & TERRORISM & $\begin{array}{l}12 \\
\langle 8\rangle\end{array}$ & 04,05 \\
\hline C & CIVIL SOCIETY ORGANIZING FOR REFUGEES & 12 & $04,05,06,09,11$ \\
\hline$E$ & REFUGEE SETTLEMENT DEBATES & 10 & $03,04,05,06$ \\
\hline $\mathrm{F}$ & MARE NOSTRUM/FRONTEX OPERATIONS & 10 & 02,04 \\
\hline $\mathrm{F}$ & RESPONSIBILITY ITALY/EU & 8 & $06,11,12$ \\
\hline $\mathrm{H}$ & WALLS IN EUROPEAN BORDERS & 8 & $01,06,09,10,12$ \\
\hline $\mathrm{H}$ & RIGHT WING/LEFT WING DISCUSSION IN ITALY & 8 & $05,06,07,09$ \\
\hline $\mathrm{H}$ & BORDER CONTROL TIGHTENED & 7 & $06,09,10,12$ \\
\hline $\mathrm{J}$ & Political interventions in AfroMed countries & 7 & $02,04,06,09$ \\
\hline $\mathrm{L}$ & RefugeE BIO/PATHWAY & 6 & $05,06,07,09,11$ \\
\hline $\mathrm{G}$ & ANTI-BOATS PLAN & 5 & $04,05,06$ \\
\hline $\mathrm{F}$ & EUROPEAN IDENTITY \& HOSTING ATTITUDE & 5 & $04,08,09$ \\
\hline $\mathrm{L}$ & REFUgeE CHILdREN 〈InC. Aylan HuRdI〉 & 5 & $06,09,11$ \\
\hline$E$ & INLAND PRESSURE 〈CHAOS/CAMIONS〉 & 5 & 08,09 \\
\hline $\mathrm{J}$ & Migrants in AfroMed countries & 4 & 03.05 \\
\hline$G$ & ASYLUM LAW & 4 & $05,08,11$ \\
\hline $\mathrm{J}$ & CLIMATE-INDUCED MIGRATIONS & 4 & $06,08,10,11$ \\
\hline $\mathrm{B}$ & REFUGEES COUNTRY OF ORIGIN & 4 & $06,07,09,12$ \\
\hline $\mathrm{G}$ & GERMAN WELCOME CHANGE & 4 & 09 \\
\hline $\mathrm{J}$ & OTAN AND OTHER POLITICAL MEETINGS IN ITALY & 4 & 10. I1 \\
\hline$J$ & $\begin{array}{l}\text { COOPERATION FOR THE MANAGEMENT OF MIGRANT FLOWS } \\
\text { 〈MAINLY AFRICA AND EUROPE }\end{array}$ & 3 & 10. 11 \\
\hline $\mathrm{H}$ & FEAR OF MIGRANTS AND POLITICAL CONSEQUENCES & 3 & $08,09,12$ \\
\hline C & Italian youth \& the Mediterranean situation & 3 & $06,10,12$ \\
\hline $\mathrm{B}$ & PaRIS ATtACH 〈ANTI-MIGRATION CLAIMS〉 & 3 & 11 \\
\hline $\mathrm{F}$ & SEARCH \& RESCUE + LEGAL CORRIDORS & 3 & 04,09 \\
\hline $\mathrm{F}$ & PoLItICAL AUDIT/AMNESTY INTERNATIONAL & 2 & 02 \\
\hline $\mathrm{D}$ & Profits in the MANAGEMENT of AfroMed CRISIS & 2 & 02,06 \\
\hline $\mathrm{L}$ & MIGRANTS DEMONSTRATION & 2 & 04,06 \\
\hline $\mathrm{F}$ & REFRAMING THE PROBLEM, MEASURES, OPERATIONS & 2 & 02,08 \\
\hline C & HOSTING REFUGEES BY CHURCH & 2 & 08 \\
\hline $\mathrm{K}$ & ItALIAN AfroMed PRIORITY IN LIBYA & 2 & 09, 11 \\
\hline $\mathrm{J}$ & FILIPPO GRANDI UNHCR & 2 & 11 \\
\hline $\mathrm{J}$ & UN $3^{\text {яо }}$ Pledging Conference fOR SYRIA & 1 & 03 \\
\hline $\mathrm{D}$ & REFUgEe CAMP IN BEIRUT & 1 & 07 \\
\hline $\mathrm{J}$ & INTERDICTION AREA & 1 & 07 \\
\hline C & Pope AGAINST REFOULEMENT & 1 & 08 \\
\hline $\mathrm{A}$ & SHIP LANDING AS A SYMBOL OF THE YEAR & 1 & 12 \\
\hline
\end{tabular}

Source: La Repubblica and Corriere della Sera websites, author's coding

In 2015 (Table 4), the debate around Triton/Mare Nostrum continued and led to enlarged financing of operations by Frontex, even though discourses remained much 
more focused on border and criminal control (advancing the hypothesis of drowning boats and chasing smugglers to solve the problem) rather than in search \& rescue missions. A perceived political gain was the 'fall of the Dublin wall', as put by Angelino Alfano, with the acceptance of an EU relocation plan and opening the doors of Germany.

The opening attitude was reinforced by diverse cultural projects, NGOs and lesserorganized groups of civil society. Nonetheless, this was also the year in which more walls/fences were erected in Europe (this news sample reported the cases of Bulgaria, Hungary and Austria), presented as measures to manage the growing phenomenon of asylum seeking. Shipwrecks and other boat accidents were reported during the entire year, but were more focused in April, the deadliest month, and September, when the problem became more associated with pictures of child victims, reinforcing the vulnerable visualization and the shift to greater use of the Eastern Mediterranean route. In the last part of the year, the problem of refugees was more strongly associated with terrorism and islamophobia, particularly after the Paris attack of $13^{\text {th }}$ November, and with the records of 1 million incomers and more than 3700 deaths.

This period was mostly framed by the adoption of the refugee problem to the European agenda, mainly through two discourses: refugee relocation, proposing refugees' resettlement in EU countries; and chasing smugglers, to stop mediated (criminalized) entries of new refugees into Europe. News were predominantly written in the external affairs section of both newspapers. The deadliest month, April, marked the end of the Dublin regulation and discussions about drafts of a relocation plan, which still lacked concrete assignment of responsibilities. The idea of refugee resettlement was endorsed as mandatory in all EU countries, but varied on the weight of each country's share. The discourse on smugglers' guilt was strongly reinforced, but generated unfriendly debates with neighbouring Mediterranean countries reacting to the idea of a military intervention in their territories.

After the widely visualized September 2015 accident (photo of the child victim Aylan Kurdi), the problem was reframed towards focusing on the Eastern Mediterranean route. A third round of emergency was depicted: the visualization of the problem lost racialization and gained political momentum and civil solidarity. Additionally, Italy, France and Germany suggested a common approach that was nonetheless criticised by Eastern Europe, where walls were reinvented through forbidden access to inland means of transport, security forces checked people "looking like" refugees and marked their arms with identifying numbers, and refugee camps multiplied in transit spots. The vocabulary of crisis became associated with one of collapse, particularly regarding the Greek context. The Mediterranean was seen as a cemetery, marked by the memory of a corpse of a vulnerable kid, and EU inland was not depicted as much better for the survivors. The agreement that was sought was aimed at relocating a part, not the totality, of asylum seekers, excluding those still on the move, thus subverting the very principle of the refugee protection figure.

\section{Conclusions}

For contextual background it is important to notice that, despite the former lack of association of news about migrants and refugees with the Mediterranean area, 
mediatisation of the present problem is grounded on a pre-existent phenomenon and reflection about forced migrations that already appealed to a part of the media and news consumers (public opinion).

Regarding this sample of the Italian press, 2013 outlined the construction of a humanitarian and political problem, debated mainly from Italy towards Europe. The critical event that detonated public attention was the accident of $3^{\text {rd }}$ October 2013 in Lampedusa, taken as the first framing event on the construction of this problem. Presented as a morally criticisable human dignity problem, three contextual scales could be identified as influencing the refugees' social conditions: origin (forced migrations, war and terrorism), transit (shipwrecks and other accidents, criminal smuggling and trafficking) and arrival (restrictive legislation/detention practices).

The year 2014 witnessed the growth of this problem and its resettlement consequences (main frame), maintaining the attention on new accidents and progressively considering refugees' pathways after their landing. This generated deepened discussions about detention practices, settlement in Italy, ghettoization of refugees and European possibilities for dealing with the growing number of arrivals. The European border control operation, Triton, replaced the Italian search and rescue operation, Mare Nostrum, but criticisms remained until Triton had increased financing and an enlarged coverage area.

For the period considered in this analysis, 2015 was presented as the record year, with more than 1 million Mediterranean arrivals and more than 3700 deaths (including the deadliest accident in April), and the addition of the Eastern to the Central Mediterranean Route. Relocation was key to EU plans (main frame) to solve this problem, but implied considering the important divergent positions of Southern, Eastern and Central European countries. After focusing on criminal smuggling and boats, attention was put on drafting a share system to distribute refugees among European countries. This endeavour was not consensual, and frontier walls/fences were erected in some of the most pressured transit countries.

The data gathered here may be integrated into broader representations of the social problem of refugees in the Mediterranean territory. Media contents, through the construction of symbolic representations of objective reality, constitute privileged inputs for individual consciousness and social actions. When media deepens constructions about Mediterranean refugees, the constructed problem moves closer to individual and collective zones of relevance, becoming a priority.

In this Italian media sample, the Mediterranean refugee problem has been constructed as a political priority separated from the national space, debated and with solutions sought at the international scale. Disaster-focused mediatisation, religious and civil society initiatives produced an important moralizing effect that kept the priority of integrating this problem into the political agenda while at the same time creating a field of philanthropy and a $3^{\text {rd }}$ sector market. Three levels of the political approach to this problem have been particularly important: interception (Europe vs. Italy, border control vs. search and rescue operations), criminalization (Italy - undocumented migrants, EU - smuggling) and settlement (detention, Italian resettlement and European relocation). These can be important clues for interpreting further 
developments of this social problem, as well as of the progressive development of the problem (and foreseen "solution" as it was presented in early 2016) about the East.

The Mediterranean emergent context became a symbol of the first years of the $21^{\text {st }}$ century, an identity mark strong enough to persist into at least the near future. Different from other constructions of mobile groups, the refugee problem in the Mediterranean is presented via modes, politics and territories of mobility that provide a visualization of refugees' challenges in achieving the most basic rights of citizenship.

At the administrative level, the Mediterranean territory is under negotiations for renewed transnational regulations and control devices, and in 2013-2015, important debates developed about the responsibility of different European countries (not only Southern European countries) in this matter. People in refugee-like situations are one of the most vulnerable groups in this territory of mobility, as their administrative situation metaphorically parallels the Mediterranean Sea in its transitional and liquid features.

At the level of territorial marks/features, the Mediterranean is represented as securitized, disastrous and in need of solidarity. This sea that gathers two margins with strong demographic and economic disparities (southern demographic surplus vs. higher human development indexes to the north) is the end for thousands of people who end up in the Mediterranean cemetery, and the crossing platform for the survivors who later find out that many inequalities get reinforced in inland Europe.

In sum, this social problem is constructed in relation to both the Mediterranean territory and the refugees as a social group. It presents a problem in political/security and social/solidarity terms, two fields whose attributed duties we can expect to see reorganized in the nearby future. Could this constructed problem and emergency about a common territory in crisis represent the political and moral shipwreck of Europe (de Lucas 2016) as we know it?

\section{Empirical data}

Corriere della Sera, available at http://www.corriere.it. Accessed 19 January 2016.

La Repubblica, available at http://www.repubblica.it. Accessed 29 January 2016.

Frontex (2016a) 'Central Mediterranean Route', European Agency for the Management of Operational Cooperation at the External Borders of the Member States of the European Union, available at http://frontex.europa.eu/trends-androutes/central-mediterranean-route/. Accessed 18 January 2016.

Frontex (2016b) 'Eastern Mediterranean Route', European Agency for the Management of Operational Cooperation at the External Borders of the Member States of the European Union, available at http://frontex.europa.eu/trends-androutes/eastern-mediterranean-route/. Accessed 18 January 2016. 
IOM (2016) 'Latest global figures', Missing Migrants Project, Geneva: International Organization for Migration, available at http://missingmigrants.iom.int/latest-globalfigures. Accessed 11 April 2016.

IOM (2016b) 'Mediterranean Sea - Data of Missing Migrants', Missing Migrants Project, Geneva: International Organization for Migration, available at http://missingmigrants.iom.int/Mediterranean. Accessed 4 February 2016.

UNHCR (2015) 'Mid-year statistics', Population statistics, UNHCR - The UN Refugee Agency, available at http://www.unhcr.org/statistics/mid2015stats.zip. Accessed 11 April 2016.

UNHCR (2016) 'Evolution - Mediterranean Sea', Refugees/Migrants Emergency Response - Mediterranean, UNHCR - The UN Refugee Agency, available at http://data.unhcr.org/mediterranean/regional.php. Accessed 4 February 2016.

\section{Bibliographic References}

Adoni, H. \& Mane, S. (1984) 'Media and the social construction of reality. Toward an integration of theory and research', Communication Research, 11, 3, 323-340

Baptista, L. (2004) 'Territórios lúdicos (e o que torna lúdico um território): Ensaiando um ponto de partida', in Actas dos Ateliers do V Congresso Português de Sociologia - Sociedades Contemporâneas: Reflexividade e Acção, Atelier: Cidades, Campos e Territórios, Braga: Universidade do Minho

Baptista, L. (2012) 'Le monde des mobilités. Globalisation, territoire et capital de mobilité', in F. Diogo, R. L. Gonçalves \& L. Tomás (Dir.) Les nouveles configurations de la mobilité humaine, Fribourg: Academic Press Fribourg, pp. 1523

Baudin, G. (2014) 'Sur les rapports entre identités, lieux et territoires au prisme de la transaction territoriale', in D. Vaz, \& G. Baudin (Orgs.) Transação territorial Novas relações cidade-campo, V. N. Famalicão: Húmus, pp. 31-42

Bauman, Z. (2000) Liquid modernity, Cambridge/UK \& Malden/USA: Polity

Berger, P. \& Luckmann, T. (1966) The social construction of reality, Garden city/New York: Doubleday and Co.

Castles, S., de Haas, H. \& Miller, M. (2014) The Age of Migration. International Population Movements in the Modern World, $5^{\text {th }}$ ed., Hampshire/UK \& New York/USA: Palgrave Macmillan

D'Angelo, P. (2002) 'News framing as a multiparadigmatic research program: a response to Entman', Journal of Communication, 52, 4, 870-888

De Lucas, J. (2016) Mediterráneo: El naufragio de Europa, $2^{\text {nd }}$ ed., Valencia: Tirant Humanidades. 
Entman, R. (1993) 'Framing: toward clarification of a fractured paradigm', Journal of Communication, 43, 4, 51-58

Kaufmann, V., Bergman, M. M. \& Joye, D. (2004) 'Motility: Mobility as Capital', International Journal of Urban and Regional Research, 28, 4, 745-756

Koziner, N. (2015) 'Framing: a research program for media communications studies', Revista Interamericana de Comunicação Midiática, 14, 28, 22-45

Mazzella, S. (2014) Sociologie des Migrations, Col. 'Que sais-je?', Paris: Presses Universitaires de France

Papuzzi, A. (2010 Professione giornalista. Le techniche, $i$ media, le regole, $5^{\text {th }}$ ed., Rome: Donzelli

UNHCR (2010) Convention and Protocol Relating to the Status of Refugees, Geneva: UNHCR - The UN Refugee Agency

UNODC (2004) United Nations Convention against Transnational Organized Crime and the Protocols Thereto, New York: United Nations

Urry, J. (2007) Mobilities, Cambridge/UK \& Malden/USA: Polity

Urry, J. \& Sheller, M. (2006) 'The new mobilities paradigm', Environment and Planning A, 38, 207-226

Inês Vieira has a BSE in Childhood Education (ESE/IPP), a MSc in Human Ecology and Contemporary Social Problems (FCSH/NOVA) and is currently a PhD student in Human Ecology (FCSH/NOVA). She is a researcher in CICS.NOVA, FCSH/NOVA, presently with science management duties in a European project fostering intercultural education in Russian Federation (ALLMEET - EU Tempus), and previously in national projects studying youth attitudes and perceptions. She has been monitor/teacher in environmental sociology, territory and social networks (FCSH/NOVA). Current research interests include territories and/of mobile groups (refugees, migrants, citizens, tourists), Africa-Europe mobilities and "environmental refugees".

Email: ines.vieira@fcsh.unl.pt 